Journal

of Geography,

Politics and Society

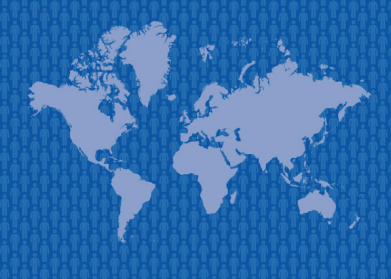

$10(4) / 2020$

\section{Journal of Geography, Politics and Society}

2020, 10(4), 49-57

https://doi.org/10.26881/jpgs.2020.4.06

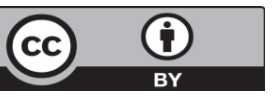

\title{
ALLOTMENT GARDENS (AG) IN THE DAYS OF THE COVID-19 PANDEMIC. THE CASE OF "ŻEROMSKIEGO" AG IN ŁASK-KOLUMNA AND “WOLINKA” AG IN ZDUŃSKA WOLA (POLAND)
}

\author{
Roman Szkup \\ Department of Urban Geography, Tourism and Geoinformation, University of Łódź, Kopcińskiego 31, 90-142 Łódź, Poland, ORCID: 0000-0002-1605-5335 \\ e-mail: roman.szkup@geo.uni.lodz.pl
}

\section{Citation}

Szkup R., 2020, Allotment Gardens (AG) in the days of the covid-19 pandemic. The case of "Żeromskiego" AG in Łask-Kolumna and "Wolinka" AG in Zduńska Wola (Poland), Journal of Geography, Politics and Society, 10(4), 49-57.

\begin{abstract}
Family Allotment Gardens (AG) are a place of rest and recreation for residents of mainly large cities. The COVID-19 pandemic, which started in China in January 2020, launched a major crisis affecting various types of human activity, including tourism and hospitality, and limited travel opportunities. For many people, especially the poorer and professionally inactive ones (including retirees and pensioners), activities on plots of Family Allotment Gardens have become the only form of active recreation. On November 5, 2020, on the official website of the international organization Office International du Coin de Terre et des Jardins Familiaux, operating since 1926, representing national organizations and associations of gardeners from 14 European countries, the following information was published: "The pandemic has confirmed it: allotment gardens are more important than ever". This article is an attempt to verify this thesis by answering the question: If and to what extent did the COVID-19 pandemic influence the behavior and recreation of allotment garden users? This was verified by a questionnaire survey conducted among users of two gardens located in the western part of the suburban area of Łódź. The analysis showed that the COVID-19 pandemic affected the behavior and rest of allotment garden users; however, the impact in the case of the studied gardens was not as large as could be expected.
\end{abstract}

\section{Key words}

allotment gardens (AG), allotment gardening, recreation in allotment gardens, COVID-19 pandemic.

Published: 31 December 2020

\section{Introduction}

The COVID-19 pandemic, which started in China in January 2020, initiated a major crisis affecting various types of human activity, including tourism (Niewiadomski, 2020) and hospitality (Napierała et al., 2020). In the pandemic era, the possibility of traveling in many regions of the world was significantly reduced (Chinazzi et al., 2020; Dinarto et al., 2020; Voth, 2020). Restricting the possibility travel for tourist and recreational purposes necessitated looking for alternative ways of rest and recreation.

Family allotment gardens fulfill many functions - in the Polish literature, allotment gardens 
are described, among others, as places of social activation conducive to the activity of professionally inactive people (including pensioners and retired persons) and as places of recreation and active rest (Duś, 2014; Mokras-Grabowska, 2020; Szkup, 2013; Szkup, Pytel, 2016). Family allotment gardens play important social functions; they are the "green lungs of cities", and for many city dwellers, a stay on a plot of land is the only opportunity to have direct contact with nature. It is also a meeting place for close and distant families, fostering their integration. Family allotment gardens also facilitate wider social integration - their specificity in this respect lies in helping to establish closer contacts with neighbors and to create small local communities (Matczak, Szkup, 2010). For many people, especially the poorer and professionally inactive ones (including retirees and pensioners), activities carried out on plots in Family Allotment Gardens are the only way to rest actively (Matczak, Szkup, 2010; Szkup, 2013; Szkup, Pytel, 2015).

In the English-language literature, great emphasis is put on the benefits of using allotment gardens; many authors mention groups of economic, social, cultural, educational, health benefits as well as benefits for the natural environment (among others, Nettle, 2010; Drescher et al., 2006; Perez-Vazquez et al., 2005). An important and increasingly more often discussed issue is the relationship between the plot and health. Most often authors discuss the health aspects of the functioning of allotment gardens, including their positive impact on their users' health (van den Berg et al., 2010), and they analyze the health significance of allotments (e.g. Armstrong, 2000; Bell et al., 2020; Brown, Jameton, 2000; Twiss et al., 2003; Turner, Henryks, 2011; Wakefield et al., 2007).

The following information appeared on November 5, 2020 on the official website of the international organization Office International du Coin de Terre et des Jardins Familiaux, operating since 1926 and representing national organizations and associations of allotment gardeners from 14 European countries: "The pandemic has confirmed it: Allotment gardens are more important than ever"(Allotment..., 2020).

This article attempts to verify this thesis by answering the question: Dis the COVID-19 pandemic influence the behavior and rest of allotment garden users and to what extent? The answer to this question has become the main goal of this study.

\section{Materials and Methods}

The research was carried out in two allotment gardens located in the cities of the Łódź agglomeration. The common feature of both cities is their location in the western part of the suburbs of Łódź, along the railway line connecting Łódź with Ostrów Wielkopolski, Wrocław and Poznań.

Stefan Żeromski Family Allotment Garden ("Żeromskiego" AG) is located in the town of Łask, in the Kolumna district, in Miła and Przedwiośnie streets. The garden complex borders only on clusters of single-family residential houses. A large forest complex and the Łask-Kolumna railway station are nearby.

The garden was founded in 1962 on the initiative of local residents who wanted to create a garden to grow their own vegetables and fruit. The garden area was originally a wet wasteland that was drained and reclaimed. Over time, a pond was dug in the garden. The garden lands have belonged to the State Treasury since its creation. Currently, "Żeromskiego" AG has 135 plots, with the total area of the garden being 5,775 ha. The garden is mostly used by the inhabitants of Łódź.

Family Allotment Garden "Wolinka" ("Wolinka" AG) is located in the city of Zduńska Wola in Lipowa Street. Next to "Wolinka" AG, there are singlefamily houses, a city bypass, a fire brigade station, a heat and power plant and a large housing estate. A few hundred meters away there are large industrial plants - Wola and Zwoltex.

Planning of the creation of "Wolinka" AG began in 1967, and the garden itself was opened in 1970. "Wolinka" AG was created on the rising tide of mass opening of allotment gardens intended for the working class in socialist Poland, on the initiative of the central authorities. Trade unions from the Wola plant largely contributed to the creation of "Wolinka" $A G$, as employees of this plant were mainly the first users of the plots. Currently, "Wolinka" AG has 237 plots, with the total area of the garden being 7,420 ha. Over $90 \%$ of the garden is used by the inhabitants of Zduńska Wola.

Research in both gardens was carried out at the end of the first wave of the COVID-19 pandemic in Poland, at the turn of August and September 2020. The main material was obtained through the questionnaire method (a questionnaire interview). A field inventory of both gardens was also carried out.

Due to the fact that there is no database of legal holders and actual users of allotment gardens in Poland (Moskalonek et al., 2020), the survey was not representative. Despite the lack of representativeness, a significant number of questionnaire 
Tab. 1. Percentage structure of the surveyed users of the studied allotment gardens

\begin{tabular}{|c|c|c|c|}
\hline & Total & $\begin{array}{l}\text { "Żeromskiego" AG } \\
\text { in Łask-Kolumna }\end{array}$ & $\begin{array}{c}\text { "Wolinka" AG in Zduńska } \\
\text { Wola }\end{array}$ \\
\hline Total number of plots & 372 & 135 & 237 \\
\hline Number of surveyed users & 117 & 54 & 63 \\
\hline Percentage of surveyed plots & 31.5 & 40.0 & 26.6 \\
\hline \multicolumn{4}{|l|}{ Sex: } \\
\hline male & 58.1 & 57.4 & 58.7 \\
\hline female & 41.9 & 42.6 & 41.3 \\
\hline \multicolumn{4}{|l|}{ Age: } \\
\hline Median age of the respondents [years] & 60.3 & 62.8 & 58.2 \\
\hline under 40 years old & 6.9 & 0.0 & 12.7 \\
\hline 40-49 years old & 12.8 & 7.4 & 17.5 \\
\hline $50-59$ years old & 23.1 & 22.2 & 23.8 \\
\hline $60-69$ years old & 35.9 & 53.7 & 20.6 \\
\hline 70-79 years old & 16.2 & 16.7 & 15.9 \\
\hline 80 years old and more & 5.1 & - & 9.5 \\
\hline \multicolumn{4}{|l|}{ Professional status: } \\
\hline unemployed [\%] & 4.3 & 0.0 & 7.9 \\
\hline employed [\%] & 36.8 & 29.6 & 42.9 \\
\hline retirees and pensioners [\%] & 59.0 & 70.4 & 49.2 \\
\hline \multicolumn{4}{|l|}{ Place of residence: } \\
\hline Łódź [\%] & 38.5 & 83.3 & 0.0 \\
\hline other towns of the Łódź agglomeration [\%] & 61.5 & 16.7 & 100.0 \\
\hline
\end{tabular}

Source: own study, based on field research in allotment gardens.

interviews were conducted - 117 (Tab. 1), i.e. almost $1 / 3$ of all users of the surveyed gardens were interviewed. As the questionnaire interview was conducted in direct contact with the respondents, despite maintaining social distance ( $2 \mathrm{~m}$ distance) and protective measures in the form of facemasks or visors, some people refused to participate in the study (in both gardens there were about $15 \%$ of such refusals). It should also be noted that despite multiple visits to the gardens, about $1 / 3$ of the plots were not used during the research period (there were no users on the plots).

Among 117 surveyed plot users, there were no people living permanently or with registered residence abroad. Almost $40 \%$ of users lived in Łódź. Among the respondents, there was a significant advantage of men $(58.1 \%)$ over women $(41.9 \%)$, which may indicate that men are more active during the COVID-19 pandemic. This conclusion is related to the research conducted by the present author in Łódź allotment gardens in 2008-2014 which showed that the gender structure of users of Łódź gardens is very similar to the gender structure of Łódź inhabitants, where there is a slight surplus of women over men (Szkup, 2013; Szkup, Pytel, 2015). The surplus of men in this study was most clearly visible among garden users aged 50-79; the median age of the respondents was 60.3 years and was higher by 2 years in the case of "Żeromskiego" AG in Łask-Kolumna. The advanced age of allotment garden users is related to their professional activity. The dominant share belonged to professionally inactive users - retirees or persons on a disability pension constituted $59 \%$ of the users, people with vocational education (48.7\%), having a large family $(72.6 \%)$ and describing their financial situation as average (71.8\%).

\section{Results and Discussion}

Due to the COVID-19 pandemic, a number of restrictions were introduced in the gardens under study. All events and competitions organized annually in the gardens, such as Allotment Plot Day, Garden Day, or competitions for the best-developed plot, were canceled. Contacts with the management of gardens were limited to a minimum, and the use of common parts of the gardens was subject to an obligation to maintain social distance and to use protective masks.

The restrictions related to the COVID-19 pandemic in Poland were reflected in the way the plot users 
Tab. 2. The way users reach (arrive at) the studied gardens

\begin{tabular}{|c|c|c|c|c|}
\hline \multirow[t]{2}{*}{$\begin{array}{l}\text { The way of arriving at the } \\
\text { garden }\end{array}$} & $\begin{array}{l}\text { "Żeromskiego" AG } \\
\text { in Łask-Kolumna* }\end{array}$ & $\begin{array}{c}\text { increase / decrease } \\
\text { due to the COVID-19 } \\
\text { pandemic }\end{array}$ & $\begin{array}{l}\text { "Wolinka" AG in } \\
\text { Zduńska Wola* }\end{array}$ & $\begin{array}{c}\text { increase / decrease } \\
\text { due to the COVID-19 } \\
\text { pandemic }\end{array}$ \\
\hline & \multicolumn{4}{|c|}{ [\%] } \\
\hline by private car & 92.6 & 17.9 & 42.9 & 0.7 \\
\hline by train & 68.5 & -18.5 & 0.0 & 0.0 \\
\hline by bike & 9.3 & 0.6 & 31.7 & 2.1 \\
\hline on foot & 0.0 & 0.0 & 28.6 & 7.0 \\
\hline city transport & 0.0 & 0.0 & 4.8 & -9.8 \\
\hline
\end{tabular}

* More than one answer could be given

Source: own study, based on field research in allotment gardens.

reached their gardens. It should be emphasized that the studied gardens are characterized by strong differentiation in terms of the places of residence of their users: the garden in Łask-Kolumna is mainly used by "visitors", i.e. residents of Łódź and the cities of the Łódź agglomeration; the garden in Zduńska Wola is used almost exclusively by the inhabitants of this city. Therefore, despite the fact that both analyzed gardens are located near railway stops, only in the case of "Żeromskiego" AG in Łask-Kolumna, the train played any role (Tab. 2). Going to the garden by train was declared by as many as $68.5 \%$, which was, however, $18.5 \%$ lower than before the pandemic. As the reason for the decrease in the share of commuting by rail, the respondents declared the need to travel in protective masks and the fear of contact with strangers.

Because of the pandemic, there was an increase in arriving by private cars, especially to "Żeromskiego" AG in Łask-Kolumna (an increase by $17.9 \%$ ). In the case of "Wolinka" AG from Zduńska Wola, significant increases were recorded in the case of arriving on foot (increase by $7.0 \%$ ) and by bicycle (increase by $2.1 \%$ ) with a significant decrease in commuting by public transport (decrease by $9.8 \%$ ).

Changes in the methods of getting to allotment gardens indicate a significant, conscious resignation of plot users from public transport in comparison to the period before the pandemic.

The surveyed users of allotment gardens were asked whether the plot in the allotment garden was their only place of rest and recreation during the COVID-19 pandemic and whether this was the case in the period before the pandemic (Tab. 3). The collected research material indicates that only for $2 / 3$ of users the plot was the only place of rest and recreation during the pandemic. Compared to the period before the pandemic, the significance of the plot as the only place for recreation increased by only $9.4 \%$.
During the pandemic, the greatest increase in the importance of the allotment garden as the only place of rest and recreation was in the case of women - an increase by $12.2 \%$, middle-aged people: $40-49$ years old - an increase by $20 \%$ and $50-59$ years old - an increase by $18.5 \%$, people in employment (professionally active) - an increase by $16.3 \%$, residents of other towns than Łódź - an increase by $18.1 \%$ and the least educated people. The pandemic did not change, or changed slightly, the importance of gardens for seniors over 60 years old and for the professionally inactive persons - retirees and pensioners. In their case, both before and during the pandemic, a plot in the garden was the most important place of recreation.

The surveyed users of allotment gardens were also asked whether the COVID-19 pandemic changed the way they spend their leisure time on the plot in any way. Only slightly more than $1 / 4$ of the users answered "yes" to this question (Fig. 1). For $72 \%$ of the respondents, the pandemic did not change recreation on the plot in any way, despite the obvious limitations resulting e.g. from restrictions on the use of common parts of the garden. The most numerous group of respondents who said that the pandemic changed their forms of recreation in the gardens were young people up to 40 years old (50\%), women (36.7\%), especially single mothers, people with higher and secondary education, and people not living in Łódź. The pandemic had the least impact on the opinions of people with primary education, people aged 40-49 and residents of Łódź.

Despite the fact that only every fourth surveyed garden user indicated that the COVID-19 pandemic affected the change in rest and recreation on the plot in any way, in their free opinions more than $80 \%$ of the respondents indicated at least one change or limitation in the use of gardens that directly resulted from the COVID-19 pandemic (Fig. 2). 
Tab. 3. Answers to the question: Was/Is the allotment garden the only place of rest recreation before the pandemic and during the pandemic?

\begin{tabular}{|c|c|c|c|c|c|}
\hline & \multicolumn{2}{|c|}{$\begin{array}{l}\text { before the pandemic } \\
\text { in } 2018-2019\end{array}$} & \multicolumn{2}{|c|}{ during the 2020 pandemic } & \multirow{2}{*}{$\begin{array}{c}\text { increase / decrease } \\
2020 \text { / 2018-2019 }\end{array}$} \\
\hline & YES & NO & YES & NO & \\
\hline & \multicolumn{5}{|c|}{ [\%] } \\
\hline Total & 57.3 & 42.7 & 66.7 & 33.3 & 9.4 \\
\hline \multicolumn{6}{|l|}{ Sex: } \\
\hline male & 61.8 & 38.2 & 69.1 & 30.9 & 7.4 \\
\hline female & 51.0 & 49.0 & 63.3 & 36.7 & 12.2 \\
\hline \multicolumn{6}{|l|}{ Age: } \\
\hline under 40 years old & 12.5 & 87.5 & 12.5 & 87.5 & 0.0 \\
\hline $40-49$ years old & 20.0 & 80.0 & 40.0 & 60.0 & 20.0 \\
\hline $50-59$ years old & 40.7 & 59.3 & 59.3 & 40.7 & 18.5 \\
\hline $60-69$ years old & 76.2 & 23.8 & 81.0 & 19.0 & 4.8 \\
\hline $70-79$ years old & 78.9 & 21.1 & 84.2 & 15.8 & 5.3 \\
\hline 80 years old and more & 83.3 & 16.7 & 83.3 & 16.7 & 0.0 \\
\hline \multicolumn{6}{|l|}{ Education: } \\
\hline higher & 37.5 & 62.5 & 50.0 & 50.0 & 12.5 \\
\hline secondary & 48.8 & 51.2 & 53.7 & 46.3 & 4.9 \\
\hline vocational & 61.4 & 38.6 & 71.9 & 28.1 & 10.5 \\
\hline primary & 81.8 & 18.2 & 100.0 & 0.0 & 18.2 \\
\hline \multicolumn{6}{|l|}{ Professional status: } \\
\hline employed & 25.6 & 74.4 & 41.9 & 58.1 & 16.3 \\
\hline retirees and pensioners & 78.3 & 21.7 & 82.6 & 17.4 & 4.3 \\
\hline
\end{tabular}

Source: own study, based on field research in allotment gardens.

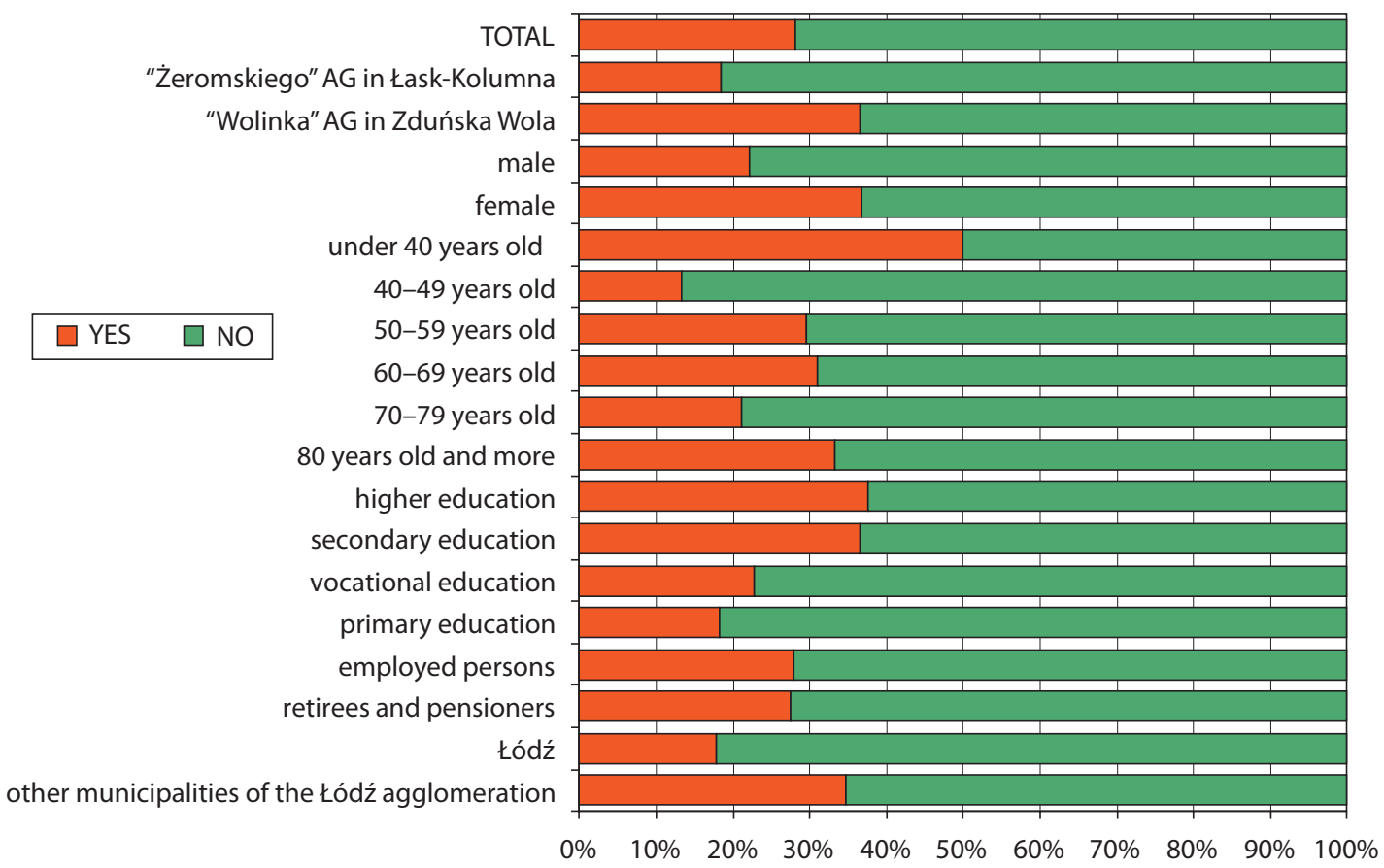

Fig. 1. Answers to the question: Did the COVID-19 pandemic change the form of rest and recreation on the plot in any way?

Source: own study, based on field research in allotment gardens. 
In the respondents' opinions, the most frequently indicated limitations directly resulting from the COVID-19 pandemic included restricting the possibility of common feasts (84.6\%) and limiting the possibility of social meetings on the plot $(75.2 \%)$, and only then - limiting the possibility of resting with the family (53.8\%), limiting contacts with other allotment gardeners (53.0\%). A very small percentage of the respondents pointed to difficulties in getting to the garden as a limitation (2.6\%).

The respondents were also asked to indicate how the COVID-19 pandemic influenced their frequency

Restrictions on getting to the allotment garden

Limiting contacts with other gardeners

Limiting the possibility of resting with the family

Limiting the possibility of social meetings on the plot

Limiting the possibility of common feasts

Reducing the frequency of visits to the plot

Neither increasing nor reducing the frequency of visits to the plot

Increasing the frequency of visits to the plot of visiting allotment gardens (Fig. 2). Only $5.1 \%$ of the respondents stated that the pandemic reduced the frequency of their visits, while $43.6 \%$ of the respondents stated that the pandemic had no impact on their frequency of visiting the plot. The claim about the great importance of rest and recreation in allotment gardens in the pandemic era was confirmed by the opinions indicating the increase in the frequency of visits to the gardens - this opinion was expressed by more than half of the respondents (51.3\%).

The surveyed users of allotment gardens were also asked to answer the question - Is there

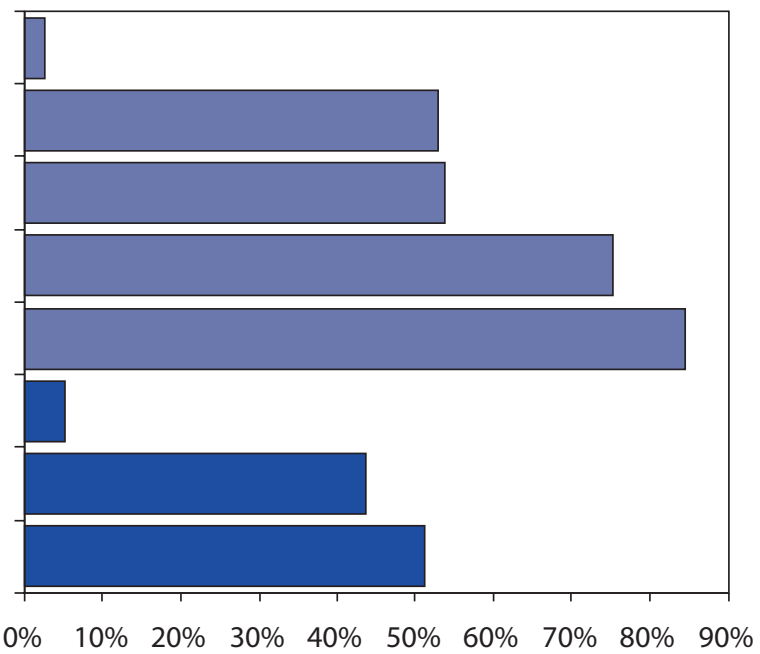

Fig. 2. Changes and restrictions in using gardens due to the COVID-19 pandemic in the respondents' opinions Source: own study, based on field research in allotment gardens.

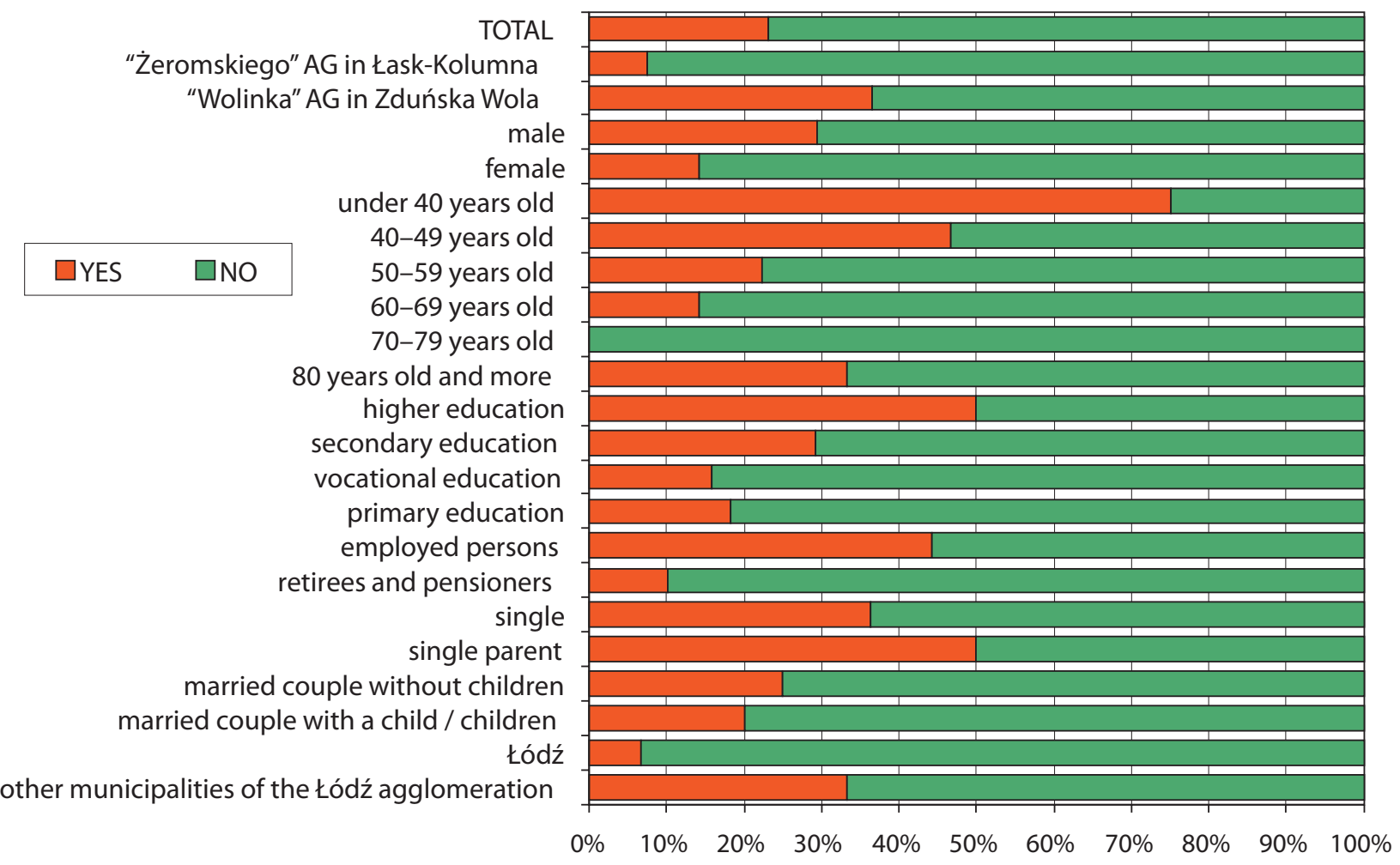

Fig. 3. Answers to the question: Can you be infected with coronavirus during your stay on the plot?

Source: own study, based on field research in allotment gardens. 
a possibility of contracting coronavirus during the stay in the allotment gardens? (Fig. 3). More than $3 / 4$ of the respondents stated that, in their opinion, there is no such possibility, while $23.1 \%$ of the respondents noticed the risk of contracting the virus. The lack of possibility to become infected during their stay on the plot was most often indicated by the oldest people, aged 60-79 years. A similar opinion was also expressed by users of plots living in Łódź (93.3\%) and those using "Żeromskiego" AG in Łask-Kolumna (92.6\%). The possibility of contracting coronavirus was most often indicated by young men using the "Wolinka" AG in Zduńska Wola, those working and with higher education. The possibility of infection was also indicated by single parents.

Another question that the respondents had to answer was their assessment of whether or not their allotment garden is - in the context of the COVID-19 pandemic - the only safe place for recreation. Only $0.9 \%$ of all respondents indicated that their allotment garden is, in their opinion, not a completely safe place (Fig. 4), which in the context of the answer to the previous question may be surprising. There is a paradox - despite the fact that every fourth user sees a possibility of contracting coronavirus while being in the garden, over $99 \%$ of the respondents consider this garden as a completely safe place in the context of the COVID-19 pandemic.
As a dangerous place in the context of the possibility of coronavirus infection, the garden was identified especially by people aged $40-49$, professionally active persons and holders of plots in "Wolinka" AG in Zduńska Wola. At the opposite extreme, there is "Żeromskiego" AG in Łask-Kolumna, where none of the users stated that, in their opinion, staying in this garden was pandemically dangerous.

The respondents' opinions showing that during the pandemic the allotment garden has become the only safe place to rest (Fig. 4) are also a significant result of the research in view of the above question. This was declared by $47.0 \%$ of all respondents and as many as $75.9 \%$ of users of "Żeromskiego" AG in ŁaskKolumna who permanently live in Łódź. The oldest users, especially those over 80 years old $(75.0 \%)$ and poorly educated people made similar statements.

The last issue raised in the questionnaire interview with allotment garden holders was the problem of using the safety measures recommended during the COVID-19 pandemic in the gardens (Fig. 5).

The conducted research clearly shows that hand disinfection is common among plot users (81.5\%), and other safety measures are generally observed only in common parts of the gardens. In the common areas, social distance is kept (89.7\%), and protective masks are worn (82.1\%). However, it is not common to wear protective gloves (13.7\%). On the

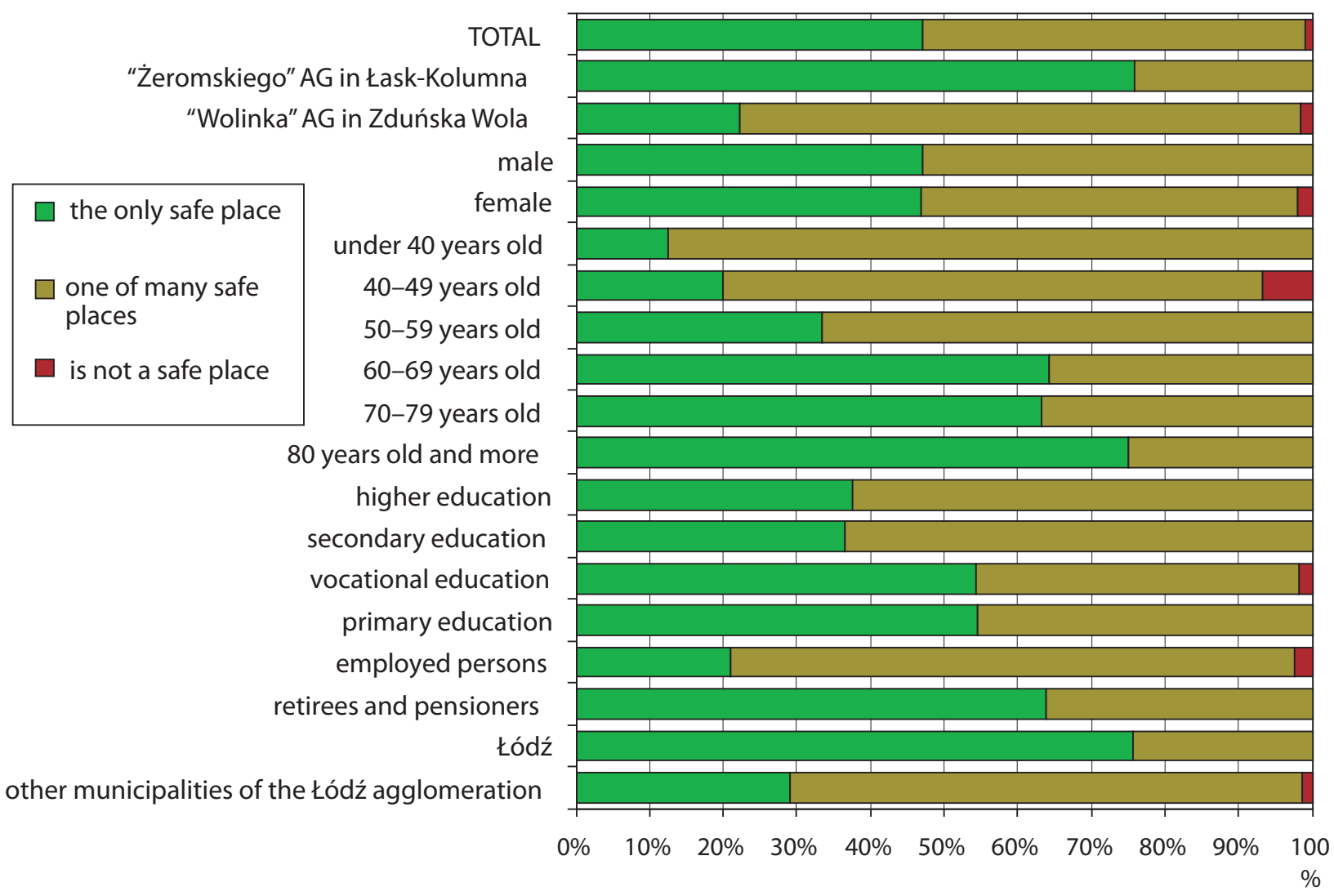

Fig. 4. Safety assessment of stays in allotment gardens

Source: own study, based on field research in allotment gardens. 


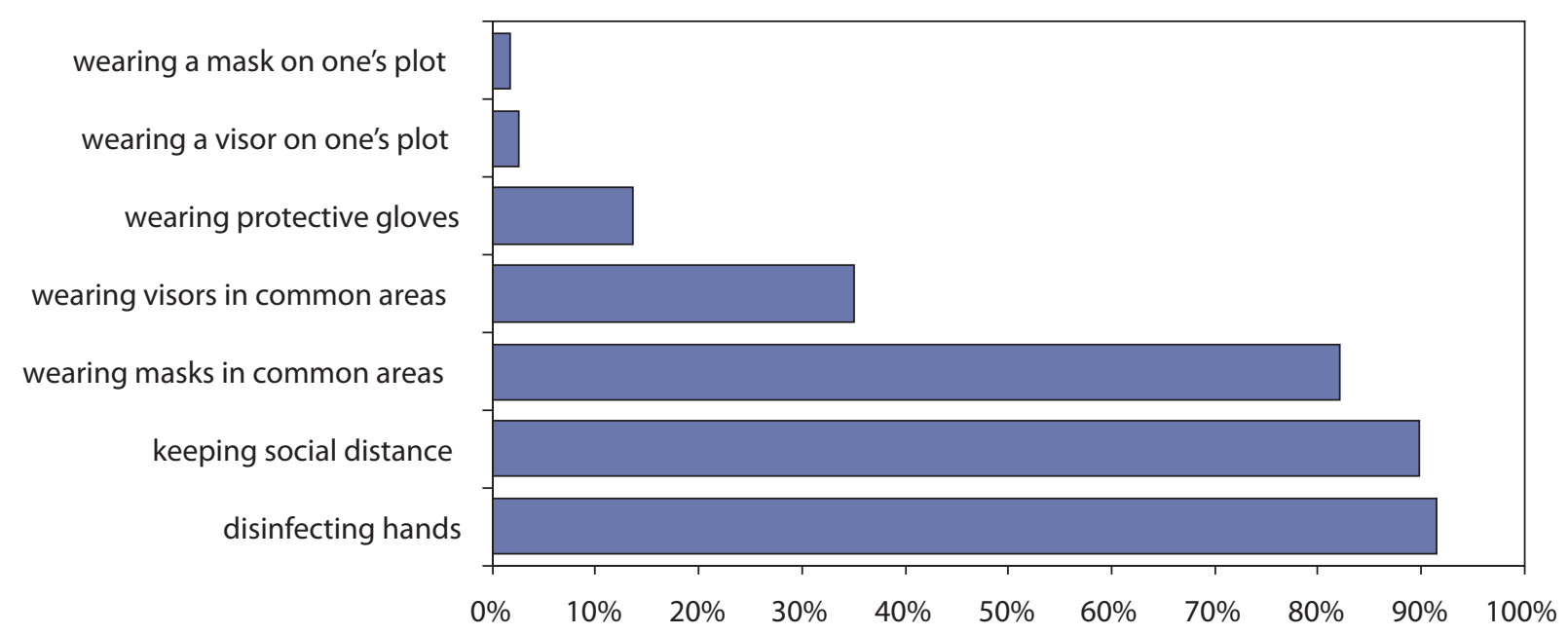

Fig. 5. Safety measures applied while visiting allotment gardens

Source: own study, based on field research in allotment gardens.

other hand, pandemic recommendations are generally ignored when the respondents are on their plots - only about $3 \%$ use protective masks or visors. This clearly shows that almost every plot user in the studied allotment gardens feels completely safe on their plot.

\section{Conclusions}

The analysis of the collected research material shows that the thesis: "The pandemic has confirmed it: Allotment gardens are more important than ever" should be verified only partially positively. The COVID-19 pandemic influenced the behavior and recreation of allotment garden users; however, in the case of the studied gardens, this impact was not as large as could be expected.

The state of development and the look of plots in the gardens indicate that a significant part of both gardens (approx. $1 / 3$ of the plots) is not used. It cannot be authoritatively stated on this basis that only the pandemic has a direct impact on this situation. It seems, however, that the pandemic situation in the country discouraged a significant number of users from visiting allotment gardens.

The fact that only for approx. $66 \%$ of the respondents, the allotment garden has become the only place to rest in the pandemic era, even though the safety of such rest is highly valued, is also a confirmation of only partial verification of the thesis postulated in the introduction. The paradox is that despite the fact that every fourth user sees a possibility of contracting coronavirus while staying in the garden, for over $99 \%$ of the users this garden is a completely safe place in the context of the COVID-19 pandemic, where precautionary measures against the pandemic, such as social distancing, protective masks and visors, and hand disinfection are commonly used (especially in common areas).

According to the author of the article, the research should be repeated in the spring of 2021. It is highly probable that the research results presented in the article and the attitudes of allotment garden users in Poland were influenced by the very timing of the research - the turn of August and September 2020, i.e. at the end of the first wave of the pandemic. At that time, the restrictions were significantly loosened and official messages from Polish state authorities indicated that the COVID-19 pandemic in Poland was under control.

\section{Acknowledgment}

Students of the University of Łódź who collected materials for their bachelor's theses, Aleksandra Marczyk ("Żeromskiego" AG) and Magdalena Rosiak ("Wolinka" AG), participated in collecting data.

\section{References}

Allotment gardens: where urban farming is old-school, 2020, Office International du Coin de Terre et des Jardins Familiaux, http://www.jardins-familiaux.org/nations/de/eng/ de_e_start.html (accessed 15 November 2020).

Armstrong D., 2000, A survey of community gardens in upstate New York: implications for health promotion and community development, Health and Place, 6(4), 319-327. doi: 10.1016/S1353-8292(00)00013-7

Bell S., White M., Griffiths A., Darlow A., Taylor T., Wheeler B., Lovell R., 2020, Spending time in the garden is positively associated with health and wellbeing: Results from a na- 
tional survey in England, Landscape and Urban Planning, 200, 103836. doi: 10.1016/j.landurbplan.2020.103836

Brown K., Jameton A., 2000, Public Health Implications of Urban Agriculture, Journal of Public Health Policy, 21(1), 20-39. doi: $10.2307 / 3343472$

Chinazzi M., Davis J.T., Ajelli M., Gioannini C., Litvinova M., Merler S., Piontti A.P.Y., Mu K., Rossi L., Sun K., Viboud C., Xuiong X., Yu H., Halloran M.E., Longini Jr. I.M., Vespignani A., 2020., The effect of travel restrictions on the spread of the 2019 novel coronavirus (COVID-19) outbreak, Science, 368(6489), 395-400. doi: 10.1126/science.aba9757

Dinarto D., Wanto A., Sebastian L.C., 2020, Global Health Security-COVID-19: Impact on Bintan's tourism sector, RSIS Commentaries, 033, Nanyang Technological University, https://hdl.handle.net/10356/137356 (accessed 21 October 2020).

Drescher A.W., Holmer R.J., laquinta D.L., 2006, Urban Homegardens and Allotment Gardens for Sustainable Livelihoods: Management Strategies and Institutional Environments, [in:] B.M. Kumar, P.K. Nair (eds.), Tropical Homegardens, Springer, Dordrecht, 317-338. doi: 10.1007/978-1-4020-4948-4_18

Duś E., 2014, Recreational use and health functions of allotments gardens in the Katowice conurbation, Poland, Environmental \& Socio-economic Studies, 2(2), 16-25. doi: 10.1515/environ-2015-0034

Matczak A., Szkup R., 2010 Społeczna funkcja Rodzinnych Ogrodów Działkowych (ROD). Przykład ROD w Łodzi (Eng. Social function of the Allotment Gardens. Case study of Łódź), [in:] S. Sitek (ed.), Stare i nowe problemy badawcze w geografii społeczno-ekonomicznej. Zeszyt 1, (Eng. "Old and New" Research Problems in Social and Economic Geography Vol. 1), Polskie Towarzystwo Geograficzne Oddział Katowicki, Sosnowiec, 179-198.

Mokras-Grabowska J., 2020, Allotment gardening in Poland new practices and changes in recreational space, Miscellanea Geographica - Regional Studies on Development, 24(4), ahead of print. doi: 10.2478/mgrsd-2020-0030

Moskalonek Ż., Połom M., Puzdrakiewicz K., 2020, Changes in the Function of Allotment Gardens in an Attractive Location Based on the Example of Tri-City in Poland, Land, 9(11), 464. doi: 10.3390/land9110464

Napierała T., Leśniewska-Napierała K., Burski R., 2020, Impact of Geographic Distribution of COVID-19, Cases on Hotels' Performances: Case of Polish Cities, Sustainability, 12(11), 4697. doi: 10.3390/su12114697

Nettle C., 2010, Growing Community: Starting and nurturing community gardens, Health SA Government of South Australia and Community and Neighbour and Centers Association Inc., Adealide.

Niewiadomski P., 2020, COVID-19: From temporary de-globalisation to a re-discovery of tourism?, Tourism Geographies, 22(3), 651-656. doi: 10.1080/14616688.2020.1757749

Perez-Vazquez A., Anderson S., Rogers A.W., 2005, Assessing benefits from allotments as acomponent of urban agriculture in England, [in:] L.J.A. Mouget (ed.), Agropolis: the social political and environmental dimensions of urban agriculture, Earthscan and IDRC, London. doi:10.4324/9781849775892-18
Szkup R., 2013, Użytkowanie rodzinnych ogrodów działkowych (ROD) przez społeczność wielkomiejską. Przykład Łodzi (Eng. Use of allotment gardens by a metropolitan community. The example of Łódź), Wydawnictwo Uniwersytetu Łódzkiego, Łódź.

Szkup R., Pytel S., 2015, Rodzinny Ogród Działkowy (ROD) jako miejsce wypoczynku i aktywności seniorów (Eng. Allotment Garden as a place for seniors relaxation and activity), [in:] [in:] S. Sitek (ed.), Stare i nowe problemy badawcze w geografii społeczno-ekonomicznej. Zeszyt 6, (Eng. "Old and New" Research Problems in Social and Economic Geography Vol 6), Polskie Towarzystwo Geograficzne Oddział Katowicki, Sosnowiec, 103-113

Szkup R., Pytel S., 2016, Rodzinne Ogrody Działkowe (ROD) w przestrzeni dużego miasta. Przykład Łodzi (Eng. Allotment Gardens in the big city. Case study of Łódź), Prace Komisjii Krajobrazu Kulturowego, 32, 109-124.

Turner B., Henryks J., Pearson D., 2011, Community gardens: sustainability, health and inclusion in the city, Local Environment, The International Journal of Justice and Sustainability, 16(6), 489-492. doi: 10.1080/13549839.2011.595901

Twiss J., Dickinson J., Duma S., Kleinman T., Paulsen H., Rilveria L., 2003, Community gardens: lessons learned from California healthy cities and communities, American Journal of Public Health, 93(9), 1435-1438. doi: 10.2105/ ajph.93.9.1435

van den Berg A., van Winsum-Westra M., de Vries S., van Dillen S., 2010, Allotment gardening and health: acomparative survey among allotment gardeners and their neighbors without an allotment, Environmental Health, 9, 74. doi: 10.1186/1476-069X-9-74

Voth J., 2020, Trade and travel in the time of epidemics, [in:] R. Baldwin, B. diMauro (eds.), Economics in the Time of COVID-19, Centre for Economic Policy Research Press, London, 93-96.

Wakefield S., Yeudall F., Taron C., Reynolds J., Skinner A., 2007, Growing urban health: community gardening in south-east Toronto, Health Promotion International, 22(2), 91-101. doi: 10.1093/heapro/dam001 